\title{
(2) \\ DEVELOPMENT AND IMPROVING STUDENTS' EXPERIMENTAL SKILLS THROUGH STEM ACTIVITIES
}

\author{
Violeta Šlekienè, Vincentas Lamanauskas \\ Šiauliai University, Lithuania
}

\begin{abstract}
There are some trends currently being monitored in the country: interest in science studies and related professions is decreasing; unsatisfactory results of international student achievement research (PISA, TIMSS). In order to make students more interested in natural sciences and to motivate them to relate their life to STEAM activities, it is appropriate to encourage students to engage in independent research and to discover the joy of discovery. One of the ways to solve this problem is the students' practical experimental activity in the laboratories of University. In this way, students not only get to know the laws of science, new technologies, but also carry out experiments, research and projects.

The research analyses the usage of STEAM program "Cognition of Energy and Thermal Processes" for students of ninth (1st Gymnasium) grades in order to deepen and broaden the knowledge of natural science education, develop practical abilities of students and their scientific researcher's competence. Students are advised to do five experimental works in this field. The program engages a basic educational method - inquiry-based learning. The results of the pedagogical experiment and the questionnaire survey are discussed. It can be stated that educational experimental activities are necessary and useful for students. By using these experimental activities, students can be provided with educational material in an attractive form, which stimulates the interest in the subject. Program participants have deepened and expanded their knowledge of energy and thermal processes in nature. Students improved their competence in natural science research. They learned how to plan and perform experiments, acquired the ability to formulate hypotheses, to make assumptions, to analyse and explain results, and to formulate reasoned conclusions. Students acquired practical skills to work properly and safely with devices and tools (computer systems Nova 5000 and Xplorer GLX, temperature, humidity sensors, caliper, scales, etc.) Students liked to be young researchers; they felt the joy of discovery by practically experimenting and independently exploring natural phenomena.
\end{abstract}

Keywords: experimental skills, science learning system, inquiry-based learning, STEAM education.

\section{Introduction}

There is a great shortage of STEAM professionals in the labour market, so there is a need to educate young, gifted people who are ready to meet future challenges and be able to cope with them. It is not enough for a contemporary student to have only knowledge; modern education has to teach students to learn independently, to become responsible for their learning and development. The ability to solve problems - has become one of the essential features of employees, but critical thinking, creativity or teamwork - are not less important. The focus of educators is on the development of competencies. STEAM education is designed so that students have the knowledge and competencies to enter the labour market and can compete there. Contemporary trends in STEAM education include an integrated (Lamanauskas, 2010), interdisciplinary education that ignores the boundaries of subjects, providing interdisciplinary concepts for students to create a holistic view of the 
world. Science, Technology, Engineering, Arts and Mathematics combine to educate the student in a holistic way.

Most educational strategists, scientists, and practitioners in advanced countries keep up-to-date STEM subjects and their teaching, taking into account the rapid change in the field of science and technology and the rise of interdisciplinary integration. Fan and $\mathrm{Yu}$ (2016) pointed out that STEM education was focused on curriculum reform in many countries. This is because a number of advanced countries have fully realized that students' academic performance in science, technology, engineering and mathematics determines the country's economic development and competitiveness.

Emphasis is placed on student-centred, constructivist education responding to the abilities of each student and suitable for all students. Worldwide practice uses various methods for updating and promoting STEM subjects. Many scientists suggested that inquiry-based learning strategy should be used to promote technology exploration, to practice teaching at a higher level, and strengthen the effect of STEM. According to many scientists, inquiry-based learning approach should be applied in schools (Abdi, 2014; Connor et al., 2015; DeJarnette, 2012; Erickson, 2013; Filippi \& Agarwal, 2017; Kennedy \& Odell, 2014; Kelley \& Knowles, 2016; Krajcik \& Delen, 2017; Lee, 2011; English, 2016; Stohlmann et al., 2012; Yakman \& Lee, 2012; Lai, 2018; Gormally et al., 2009). Inquirybased learning strategy is closely linked to project-based learning approach, as students often need to look for information and perform a small "research" in their project. Research has shown that project-based learning approach can increase students' interest in STEM subjects; this way of teaching involves students in real problem-solving, collaboration and product development process. Using a project-based approach to learning improves students' motivation and outcomes (Laboy-Rush, 2011), project-based education is more effective than traditional education approach (Han et al., 2016). Problem solving is a very important ability for the twenty-first century, so practitioners and researchers encourage the implementation of problem-based learning strategy in schools (U.S. STEM Task force, 2014; Billiar et al., 2014; Brush \& Saye, 2017; Harper, 2017; Honey et al., 2014; Kelley \& Knowles, 2016; Horak \& Galluzzo, 2017; Lou et al., 2011). The advantages of problembased learning are distinguished: students develop a broad and flexible knowledge; develop effective problem-solving skills; acquire lifelong learning skills; learn to collaborate effectively; become deeply motivated to learn. The problem-based learning creates a better approach to STEM subjects and encourages interest in STEM careers. Project-based learning allows students to acquire and apply integrated STEM knowledge. Scientists recommend using problem-based learning approach to integrated STEM subjects.

All these educational strategies can help us deliver deep and meaningful science education, increasing the interaction between the student and the concepts under investigation. It is obvious, that modern science education must be accepted as a bridge between scientific research and society, science education definitely is a core component of educatedness (Lamanauskas, 2007).

Interactive, multimedia experience cannot replace the real laboratory work but can enhance the learning process of many students, help them find the relation between the theoretical principles and the observed behaviour in an easy and intuitive way (Avouris et al., 2001). Since science is an experimental science, the role of lab-work in science education has been often given attention by research studies (Bernhard \& Norrköping, 2001; Harms, 2000; Sassi, 2001). 
Inquiry is an active learning process in which students answer research questions through data analysis. One might argue that the most authentic inquiry activities are those in which students answer their own questions through analysing data they collect independently. However, an activity can still be inquiry based when the questions and data are provided, as long as students are conducting the analysis and drawing their own conclusions.

Table 1 (Bianchi \& Bell, 2008; Bell et al., 2005) presents the four-level model of inquiry (confirmation, structured, guided and open), which is used to assess instructional activities.

\section{Table 1}

Four-level Model of Inquiry

\begin{tabular}{cccc}
\hline \multicolumn{4}{l}{ Information given to the student } \\
\hline Level of inquiry & Question & Procedure & Solution \\
\hline 1 & Given & Given & Given \\
\hline 2 & Given & Given & Open \\
\hline 3 & Given & Open & Open \\
\hline 4 & Open & Open & Open \\
\hline
\end{tabular}

The four-level model illustrates how inquiry-based activities can range from highly teacher directed to highly student centred, based on the amount of information provided to the student. The salient feature of this model is the question, "How much information is given to the student?" Using this framework as a guide, lab activities can be designed at varying levels of inquiry, depending on wording and presentation. This model allows the teacher to tailor inquiry lessons to the particular readiness levels of the class. For instance, a Level 1 activity can become a Level 2 by having students complete it prior to learning the targeted concept, and a Level 2 activity can be revised easily to Level 3 simply by removing the procedural directions. The degree of complexity in an inquiry activity also varies, depending on the level of openness and the cognitive demands required.

\section{Problem}

In order to make students more interested in natural sciences and to motivate them to relate their life to STEAM activities, it is appropriate to encourage students to engage in independent research and to discover the joy of discovery. One of the ways to solve this problem is the students' practical experimental activity in the laboratories of University. Since Science is an experimental subject, the role of practical activities in science education is very important. Experimental activities are one of the main science teaching/learning methods. One of these methods is inquiry-based learning, in which students answer the research questions through data analysis. This research analysed the usage of STEAM program "Cognition of Energy and Thermal Processes" for students of ninth (1st Gymnasium) grades in order to deepen and broaden the knowledge of natural science education, develop practical abilities of students and their scientific researcher's competence. 


\section{Research Focus and Aim}

The focus of the research was science experimental activities. The main aim was to disclose the effectiveness of practical experimental work/activities in science teaching at an upper-secondary school (based on the students' opinions).

\section{Research Methodology}

\section{General Characteristic}

The research methodology is based on the provisions of the constructivist education theory underlying the structured, guided and open exploration as an effective educational technology, which promotes a positive attitude towards science, helps to apply the acquired knowledge in different situations, develops higher-level thinking skills, encourages active learning processes. There are different ways of adopting constructivism in the teaching and learning process (Bada, 2015; Steffe \& Gale, 1995).

\section{Sample}

70 students of ninth (1st Gymnasium) grades from Šiauliai Adult School, S. Sondeckis Art Gymnasium, Romuva Gymnasium, S. Daukantas Gymnasium and S. Šalkauskis Gymnasium were involved in the experiment in 2018-2019. Analysing the results of the real education process reveals the effectiveness of practical experimental work. The educational process was based on the STEAM program Cognition of Energy and Thermal Process, which was based on inquiry-based learning. Students were advised to do five experimental works at level II, as structured exploration, and level III, as guided exploration. Experimental activities use an inquiry-based approach, based on a small-scale research activity.

\section{STEAM Program "Cognition of Energy and Thermal Process"}

The program was aimed for students of ninth (1st Gymnasium) grades in order to deepen and broaden the knowledge of natural science education, develop practical abilities of students and their scientific researcher's competence, analysing energy and thermal processes and using advanced technologies in Šiauliai University laboratory. The objectives of the program were:

- Be able to plan and perform experiments, analyse and explain results, formulate reasoned conclusions.

- Learn how to work with computer systems Nova 5000 and Xplorer GLX and other devices.

- Be able to evaluate the thermal expansion of solid bodies.

- Understand the concept of specific heat and analyse its dependence on substance features.

- Understand the essential features of phase transformations by determining the specific evaporative heat of water.

- Understand and analyse the heat exchange of the human body and the environment. 
Students were asked to perform five experimental works for 2 hours each. Works were done in groups of two. Experiments were carried out at Šiauliai University laboratory using the available equipment and tools. Some works have been done using computer-based training systems Xplorer GLX and Nova 5000. The content of the proposed experimental works has been aligned with the General Programs of Basic Education.

Students were mastering energy and thermal phenomena processes, starting with the study of the thermal properties of solid state (Work 1), the specific heat of the material (Work 2), continuing with the analysis of phase transformations and heat exchange processes (Work 3,4) and completing with the analysis of the phases of energy (Work 5).

Experimental works were carried out at level II as a structured inquiry. Students were provided with a consistent workflow and a list of research tools. Based on the goal and working according to the given description, the students formulated and checked the hypothesis, made measurements and calculations, drew the appropriate graphs, made conclusions and generalizations. As the results of the proposed works are not known in advance, there was an opportunity for discussion in groups. Analysing and discussing results was effective when experiments were done in pairs. Students learned how to work with devices and tools, developed skills in experimentation, drawing and analysing graphs. Some of the experiments were offered at level III as a coordinated inquiry. The subject of the inquiry and a list of research tools were known to the students, but the workflow was not provided. Students formulated the hypothesis and planned the workflow themselves. Working in groups was effective because communication skills were developed when the right way of working was sought.

\section{Instrument}

In order to evaluate the students' opinion on this program a survey has been carried out. The specific statements that would become meaningful indicators for identifying students' general approach to experimental works were formulated in the questionnaire. The interval (five points) scale was used in the questionnaire. Questions or statements were coded on the 5-point Likert scale: "I totally agree", "I agree", "Doubt", "I do not agree", "I completely disagree" (or similar). At the end of the questionnaire, open-ended questions were asked, in which respondents were asked to express their opinion and expectations in writing. In order to process open-ended questions, multiple data reading and text comprehension have been used. Significantly similar expressions of respondents were combined into meaningful categories.

\section{Statistical Data Analysis}

Closed-ended questions were processed using statistical analysis techniques. Data were processed using the SPSS (Statistical Package for Social Sciences) software. Methods of descriptive statistical analysis were used for the analysis of the research data. In order to calculate the Positive Opinion Index (POI) for each statement of the questionnaire, the data on the interval scale was transformed into the ratio scale. The Positive Opinion index may vary from 0 to 1 . If the positive opinion $(P O)$ index is closer to the 1 , then this statement is more significant, more important for the respondents. Differences in results across groups of respondents were tested by parametric hypotheses about group equality. 


\section{Research Results}

It can be stated that experimental activity is a necessary and currently integral part of the educational process. By using the experiment, students can be provided with educational material in an attractive form, which stimulates the interest in the subject.

The questionnaire survey of the respondents showed that the most important reason for the students to be interested in the subject matter is their interest in the subject. Positive opinion on this issue was $P O=.87$ (Table 2). In the students' opinion, rote learning from textbooks or notebooks does not produce good learning outcomes, $P O=.10$ (this is the weakest positive opinion in all groups). Respondents notice they need a lot of work in their lessons in order to succeed, $P O=.71$. To the question "What are the obstacles to better learning in science?" more than half of respondents said they are learning according to their capacity, $P O=.53$, or that they lack patience when they don't understand much, $P O=$ .41. Other students lack the time to study science or devote too little attention to it because it is not interesting, $P O=.30$.

\section{Table 2}

Factors Defining Successful Subject Learning

\begin{tabular}{lc}
\hline \multicolumn{1}{c}{ Factors } & Positive opinion \\
\cline { 2 - 2 } & $P O(N=70)$ \\
\hline The importance of interest in a subject & .87 \\
\hline The importance of working a lot in a lesson & .71 \\
\hline Learning according to their capacity & .53 \\
\hline There is a lack of patience when much is incomprehensible & .41 \\
\hline Science is not interesting & .30 \\
\hline The importance of learning memorable from textbooks or notes & .10 \\
\hline
\end{tabular}

All students were satisfied and interested in all the experimental work (Table 3, $P O$ $=.96)$, there were no unresolved difficulties for them $(P O=.66)$, they easily understood the experimental methods and workflow $(P O=.73)$. Less than a third of students have done similar work at school during school hours $(P O=.28)$ and a little over a third were familiar with tools and devices $(P O=.30)$. The students indicated that the experimental activities are interesting and engaging; they would like to continue such activities in the future $(P O=.87)$. Following a $t$-test analysis, no statistically significant difference on these issues between the groups (students of different schools) was fixed (zero hypothesis $\mathrm{H}_{0}$ on average equality cannot be rejected; $p>.41$ ). 
Table 3

Factors Defining Experimental Activities

\begin{tabular}{lc}
\hline \multicolumn{1}{c}{ Factors } & Positive opinion \\
\cline { 2 - 2 } & $P O(N=70)$ \\
\hline Doing experimental works was interesting & .96 \\
\hline It was not difficult to do experiment & .66 \\
\hline The experimental methodology and workflow were understandable & .73 \\
\hline I would like to continue this kind of activity in the future & .87 \\
\hline We do laboratory works at school & .28 \\
\hline All the tools and devices were known & .30 \\
\hline
\end{tabular}

Although the students felt that they were doing well in experimenting, they thought they could easily understand the methods and workflow of the experiment, but monitoring and evaluating the activities made it possible to identify the typical difficulties that students encountered in practical work. Most of the students hurry to do one or the other measurement, not fully understanding the meaning of the whole experiment. The lack of experimental skills is also evidenced by the difficulty for students to organize the work desk properly, to put tools and devices in a convenient and functional way. In most cases, students want to do everything while sitting, although this is sometimes very uncomfortable. There is a lack of basic skills to work with small auxiliary tools such as tweezers, tongs, flasks, tubes and so on.

The inquiry steps of experimental work, i.e. how students are able to formulate research problem, hypothesis, how to plan workflow, define variables, how to work with equipment and measuring devices, how to capture, process and analyse experimental data, formulate conclusions was analysed (Figure 1). $76 \%$ of the students successfully formulated a hypothesis and only $12 \%$ of the students, who have worked at inquiry level III, understood and planned the workflow correctly. $65 \%$ of the students properly processed the results, filled in the tables, drew up the graphs, performed the mathematical calculations, although only 34 percent succeeded in formulation of the conclusions.

\section{Figure 1}

The Inquiry Steps of Experimental Work

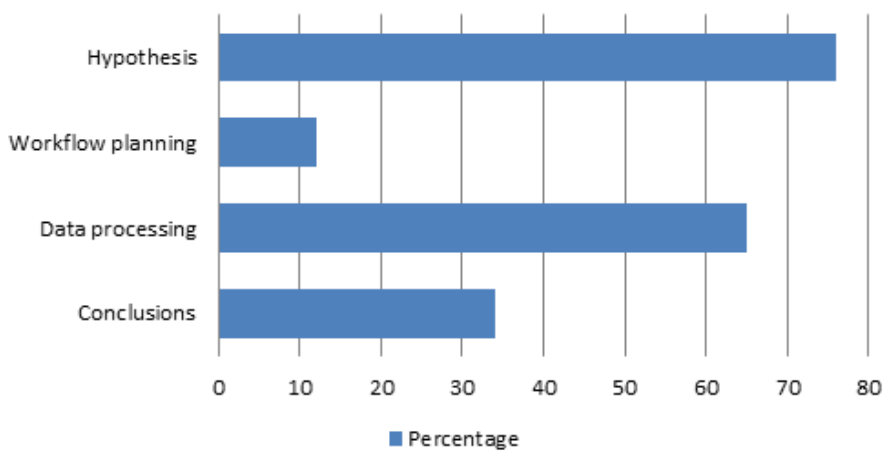


Students' attitudes towards experimental equipment and tools used at work, their complexity and expediency were explored. The following tools and equipment were evaluated: mechanical and electronic scales, mechanical and electronic caliper, mechanical and electronic thermometer, computer-learning systems Nova 5000 and Xplorer GLX. When assessing the choice of students between a mechanical and electronic measuring device, the question was asked: "If I could choose, I would measure with an electronic or mechanical measuring device and why" (Table 4).

Table 4

Choice of Measuring Device

\begin{tabular}{lccc}
\hline \multirow{2}{*}{ Device } & \multicolumn{3}{c}{ Positive opinion, $\boldsymbol{P O}(\boldsymbol{N}=\mathbf{7 0})$} \\
\cline { 2 - 4 } & Mechanical & Electronic & $\begin{array}{c}\text { There is no } \\
\text { difference }\end{array}$ \\
\hline Thermometer & .14 & .66 & .20 \\
\hline Scales & .10 & .90 & 0 \\
\hline Caliper & .14 & .99 & 0 \\
\hline
\end{tabular}

Most students prefer electronic measuring devices. The majority of students (PA $=.99$ ) chose the electronic caliper. Only one student chose a mechanical caliper, just because he was well versed in using it. For the other students with no measurement skills, a mechanical caliper seemed too complicated. They simply stated why it is necessary to measure complexly when the exact result can be seen on the display of the electronic device without much effort.

Similar arguments were made when choosing electronic scales and electronic thermometers. A small part of the students were interested in using mechanical scales ( $P O$ $=.10)$, but most of them chose electronic scales $(P O=.90)$. Some of the students who are accustomed to a household mechanical thermometer have given priority to this one $(P O=.14)$, while others who have used both thermometers have indicated that there is no difference $(P O=.20)$, the rest of the students chose the electronic thermometer $(P O=.66)$.

Students had the opportunity to work with Science Learning Systems Xplorer GLX and Nova 5000. The Xplorer GLX (Figure 2) is a data collection, graphing, and analysis tool designed for science students and educators. The Xplorer GLX supports up to four sensors simultaneously, in addition to two temperature probes and a voltage probe connected directly to specialized ports. The Xplorer $G L X$ is fully functional stand-alone handheld computing device for science. With or without a computer, capture and analyse live data anytime and anywhere. Nova 5000 integrates standard computer functionality with scientific data logging and math software (Figure 3). The Nova 5000 includes the following Soft Maker applications for advanced office functionality.

Students enjoyed working with Science Learning Systems Xplorer GLX and Nova 5000. Comparing the advantages and disadvantages of the Xplorer GLX and Nova 5000, $X$ plorer $G L X$ was relatively better $(P O=.91)$ than Nova $5000(P O=.78)$. They emphasized that Xplorer GLX is easier to manage and the Nova 5000 is quite inert and slow to operate, often malfunctioning. 
Students were asked to distinguish the essential aspects of these Science Learning Systems. The students highlighted the following key points.

- Nova 5000 and Xplorer GLX make their activities closer to real research work.

- Promote motivation, interest in teaching.

- Experiment becomes more interesting; the phenomena can be observed and investigated, which is difficult to do with conventional devices.

- A lot of mathematical knowledge is required in order to analyse the obtained results.

- Accuracy of the results. Fast and accurate data processing and graphical presentation. Big opportunities for data analysis.

- Nova 5000 and Xplorer GLX are too complicated to use in every lesson.

- Lack of skills to use, need of practical tips, advice.

Students were asked to write their own opinion on the experimental work, difficulties and experience. Several categories of students' statements can be distinguished:

- Students, who performed an experiment at level III, as coordinated inquiry, argued that some aspects of the activity put some stress on them and demanded constant efforts to find out what to do and how to do it, as there were no additional instructions to which they were accustomed.

- Students have stated that they have acquired the skills of learning and applying knowledge to real situations.

- Students have acquired skills in experimentation, working with laboratory equipment.

- Students felt confident in the laboratory and understood the essence of their work.

Some opinions of students:

- "I liked these activities, especially I liked working with Xplorer $G L X$, with which it is possible to follow the live process, to monitor its graphical representation, to revise the calculations. Similarly, I liked working with Nova, but I liked GLX more".

- "I liked experimenting in a real university lab, doing various measurements with different devices. I think it would be more interesting and better to learn so".

- "I enjoyed exploring real processes. It was new to me; we do not do such work at school. On the other hand, it was very difficult, many new devices and equipment, it was not easy to formulate hypotheses and then draw conclusions".

\section{Conclusions}

It can be stated that in order to strengthen the interest of students in science and to achieve better learning outcomes, it is necessary to organize the education process so that it would be interesting for students. By applying inquiry-based learning, students' experimental abilities and skills are developed, curiosity of students is stimulated, and interest in the subject is encouraged. The new, favourite activity of the students is of great importance for better learning outcomes.

It can be stated that the experimental training activity is a necessary and currently integral part of the educational process. By using the experiment, students can be provided with educational material in an attractive form, which stimulates the interest in the subject. 
Positive opinions of students towards STEAM training programs suggest that it is appropriate to use such programs when teaching science.

The typical difficulties that students encounter in practical work were identifying. Most of the students hurry to do measurement, not fully understanding the meaning of the whole experiment. The lack of experimental skills is also evidenced by the difficulty for students to organize the work desk properly. There is a lack of basic skills to work with small auxiliary tools such as tweezers, tongs, flasks, tubes and so on.

The research showed that students formulate the research hypothesis well enough, process data properly, but find it harder to plan workflow and formulate conclusions.

Program participants have deepened and expanded their knowledge of energy and thermal processes in nature. They understood the thermal expansion of the solid bodies, the concept of the specific heat of the material, the properties of the phase transformations of the material, the specific heat of evaporation of the water, the process of heat transfer of the human body and the environment.

Students deepened their competence in natural science research, learned how to plan and perform experiments, acquired the ability to formulate hypotheses, to make assumptions, to analyse and explain results, and to formulate reasoned conclusions.

Acquired practical skills to work properly and safely with devices and tools (computer systems Nova 5000 and Xplorer GLX, temperature, humidity sensors, caliper, scales, etc.)

Students felt the joy of discovery by practically experimenting and independently exploring energy and thermal phenomena. They enjoyed being young researchers.

\section{Note}

This is a revised and expanded version of an international scientific symposium paper. The paper was recommended for republication by the symposium scientific committee.

The reference for the Symposium version is:

Šlekienè, V. (2019). The usage of STEAM program in developing and improving of students' experimental skills. In. Lamanauskas, V. (Ed.), Science and technology education: Current challenges and possible solutions. Proceedings of the $3^{\text {rd }}$ International Baltic Symposium on Science and Technology Education (BalticSTE2019) (pp. 217221). Scientia Socialis Press. http://paper.researchbib.com/view/paper/238571

\section{References}

Abdi, A. (2014). The effect of Inquiry-based learning method on students academic achievement in science course. Universal Journal of Educational Research, 2(1), 37-41, https://www.doi. org/10.13189/ujer.2014.020104

Avouris, N. M., Tselios, N., \& Tatakis, E. C. (2001). Development and evaluation of a computerbased laboratory teaching tool. Computer Applications in Engineering Education, 9(1), 8-19. https://doi.org/10.1002/cae.1001

Bada, S. O. (2015). Constructivism learning theory: A paradigm for teaching and learning. IOSR Journal of Research \& Method in Education (IOSR-JRME), 5(6), 66-70. https://pdfs. semanticscholar.org/1c75/083a05630a663371136310a30060a2afe4b1.pdf

Banchi, H., \& Bell, R. (2008). The many levels of inquiry. Science and Children, 46(2), 26-29.

Bell, R. L., Smetana, L., \& Binns, I. (2005). Simplifying inquiry instruction. The Science Teacher, 72, 30-33. 
Bernhard, J. (2003). Physics learning and Microcomputer Based Laboratory (MBL) learning effects of using MBL as a technological and as a cognitive tool. In: Psillos, D., Kariotoglou, P., Tselfes, V., Hatzikraniotis, E., Fassoulopoulos, G., \& Kallery, M. (Eds), Science education research in the knowledge-based society (pp 323-331). Springer.

Billiar, K., Hubelbank, J., Oliva, T., \& Camesano, T. (2014). Teaching STEM by design. Advances in Engineering Education, 4(1), 1-21. https://files.eric.ed.gov/fulltext/EJ1076147.pdf

Brush, T., \& Saye, J. W. (2017). Successfully implementing problem-based learning in classrooms: Research in K-12 and teacher education. Purdue University Press.

Connor, A. M., Karmokar, S., \& Whittington, C. (2015). From STEM to STEAM: Strategies for enhancing engineering \& technology education. International Journal of Engineering Pedagogy (iJEP), 5(2), 37-47. https://online-journals.org/index.php/i-jep/article/view/4458

DeJarnette, N. (2012). America's children: Providing early exposure to STEM (science, technology, engineering and math) initiatives. Education, 133(1), 77-84. https://eric.ed.gov/?id=EJ996974

English, L. D. (2016). STEM education K-12: Perspectives on integration. International Journal of STEM Education, 3(1), 3. https://doi.org/10.1186/s40594-016-0036-1

Erickson, P. W. (2013). Full STEAM ahead. American School \& University, 85(10), 36.

Fan, S., \& Yu, K. (2016). Core value and implementation of the science, technology, engineering, and mathematics curriculum in technology education. Journal of Research in Education Sciences, 61(2), 153-183. http://dx.doi.org/10.6209\%2fJORIES.2016.61(2).06

Filippi, A., \& Agarwal, D. (2017). Teachers from instructors to designers of inquiry-based science, technology, engineering, and mathematics education: How effective inquiry-based science education implementation can result in innovative teachers and students. Science Education International, 28(4), 258-270. http://www.icaseonline.net/sei/december2017/p2.pdf

Gormally, C., Brickman, P., Hallar, B., \& Armstrong, N. (2009). Effects of inquiry-based learning on students' science literacy skills and confidence. International Journal for the Scholarship of Teaching and Learning, 3(2), 16. https://doi.org/10.20429/ijsotl.2009.030216

Han, S., Rosli, R., Capraro, M. M., \& Capraro, R. M. (2016). The effect of science, technology, engineering and mathematics (STEM) project based learning (PBL) on students' achievement in four mathematics topics. Journal of Turkish Science Education (TUSED), 13 (Special issue), 3-29.

Harms, U. (2000). Virtual and remote labs in physics education. http://discoverlab.com/References/ harms1.pdf

Harper, C. (2017). The STEAM-powered classroom. Educational Leadership, 75(2), 70-74. http:// www.ascd.org/publications/educational_leadership/oct17/vol75/num02/The_STEAMPowered_Classroom.aspx

Honey, M., Pearson, G., \& Schweingruber, H. (Eds.). (2014). STEM integration in K-12 education: Status, prospects, and an agenda for research. National Academies Press.

Horak, A. K., \& Galluzzo, G. R. (2017). Gifted middle school students' achievement and perceptions of science classroom quality during problem-based learning. Journal of Advanced Academics, 28(1), 28-50. https://doi.org/10.1177\%2F1932202X16683424

Kelley, T. R., \& Knowles, J. G. (2016). A conceptual framework for integrated STEM education. International Journal of STEM Education, 3(1), 11. https://doi.org/10.1186/ s40594-016-0046-Z

Kennedy, T. J., \& Odell, M. R. L. (2014). Engaging students in STEM Education. Science Education International, 25(3), 246-258. https://files.eric.ed.gov/fulltext/EJ1044508.pdf

Krajcik, J., \& Delen, I. (2017). How to support learners in developing usable and lasting knowledge of STEM. International Journal of Education in Mathematics, Science and Technology, 5(1), 21-28. https://ijemst.net/index.php/ijemst/article/view/105/106

Laboy-Rush, D. (2011). Integrated STEM education through Project-Based Learning. https:// studentsatthecenterhub.org/resource/integrated-stem-education-through-project-basedlearning/ 
Lai, C. (2018). Using inquiry-based strategies for enhancing students' STEM education learning. Journal of Education in Science, Environment and Health (JESEH), 4(1), 110-117. https:// eric.ed.gov/?id=EJ1170947

Lamanauskas V. (2007). Science education as a core component of educatedness. Problems of Education in the $21^{\text {st }}$ Century, 1(1), 5-6. http://www.scientiasocialis.lt/pec/node/files/pdf/ Lamanauskas.Editorial.Vol.1.pdf

Lamanauskas, V. (2010). Integrated science education in the context of the constructivism theory: Some important issues. Problems of Education in the 21st Century, 25(1), 5-9. http://www. scientiasocialis.lt/pec/node/files/pdf/vol25/5-9.Lamanauskas_Vol.25.pdf

Lee, O. (2011). Effective STEM education strategies for diverse and underserved learners. Paper Prepared for the Workshop of the Committee on Highly Successful Schools or Programs for K-12 STEM Education, National Research Council, Washington, DC.

Lou, S., Shih, R., Diez, C. R., \& Tseng, K. (2011). The impact of problem-based learning strategies on STEM knowledge integration and attitudes: An exploratory study among female Taiwanese senior high school students. International Journal of Technology and Design Education, 21(2), 195-215. https://doi.org/10.1007/s10798-010-9114-8

Sassi, E. (2001). Computer supported lab-work in physics education: Advantages and problems. In: Pinto, R., \& Surinach, S. (Eds.), Physics teacher education beyond 2000 (pp. 57-64). Elsevier.

Steffe, L. P., \& Gale, J. 1995). Constructivism in education. Lawrence Erlbaum.

Stohlmann, M., Moore, T. J., \& Roehrig, G. H. (2012). Considerations for teaching integrated STEM education. Journal of Pre-College Engineering Education Research (J-PEER), 2(1), Article 4. https://doi.org/10.5703/1288284314653

U.S. STEM Task Force. (2014). Innovate: A blueprint for science, technology, engineering, and mathematics in California public education. Dublin, CA: Californians Dedicated to Education Foundation. https://www.cde.ca.gov/pd/ca/sc/documents/innovate.pdf

Yakman, G., \& Lee, H. (2012). Exploring the exemplary STEAM education in the US as a practical educational framework for Korea. Journal of the Korean Association for Science Education, 32(6), 1072-1086. https://doi.org/10.14697/jkase.2012.32.6.1072

Received 20 July 2020; Accepted 02 December 2020 
Cite as: Šlekienè, V., \& Lamanauskas, V. (2020). Development and improving students' experimental skills through STEM activities. Gamtamokslinis ugdymas / Natural Science Education, 17(2), 61-73. https://doi.org/10.48127/gu-nse/20.17.61

\section{$[0$ \\ Violeta Šlekienė}

$\mathrm{PhD}$, Associate Professor, Institute of Education, University of Šiauliai, P. Višinskio Street 25,

Šiauliai, Lithuania.

E-mail: violeta.slekiene@su.lt

Website: https://www.researchgate.net/profile/Violeta_Slekiene

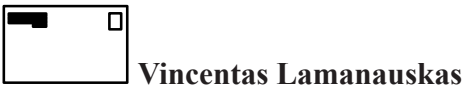

$\mathrm{PhD}$, Professor, Institute of Education, University of Šiauliai, Lithuania.

E-mail: vincentas.lamanauskas@su.lt

Website: https://projektas.academia.edu/VincentasLamanauskas

https:/www.researchgate.net/profile/Vincentas_Lamanauskas

ORCID: http://orcid.org/0000-0002-4130-7899 